\title{
Evaluation of jet engine operation parameters using conventional and alternative jet fuels
}

\author{
Anna Yakovlieva* \\ Department of Chemistry and Chemical Technology, \\ Faculty of Environmental Safety, Engineering and Technologies, \\ National Aviation University, \\ 03058, Kosmonavt Komarov Ave. 1, Kyiv, Ukraine \\ Email: anna.yakovlieva@nau.edu.ua \\ *Corresponding author
}

\section{Sergii Boichenko and Kazimierz Lejda}

Department of Combustion Engines and Transport, Faculty of Mechanical Engineering and Aeronautics, Rzeszow University of Technology,

Al. Powstancow Warszawy 8, 35-959 Rzeszow, Poland

Email: chemmotology@ukr.net

Email: klejda@prz.edu.pl

\begin{abstract}
Jet engine operation parameters using conventional and alternative jet fuels, obtained by blending with plant oil bio-additives, during bench tests were evaluated. Jet fuels were tested and compared in conditions of engine operation. It was determined that using alternative jet fuels improves jet engine thrust characteristics and reduces fuel flow. These provide more energy efficient operation of jet engine. Using alternative jet fuels results in reduction of gas temperature in the jet pipe. This contributes to durability of materials and structure of the engine against high temperature, as well as reducing of NOx emissions. The results of the study show that operational parameters of the jet engine powered with new alternative jet fuels completely satisfy exploitation norms set in specification for tested engine. Alternative jet fuels, proposed in the study, may be used as a working body of the jet engine without a need of making changes in its design.
\end{abstract}

Keywords: jet engine; jet fuel; alternative fuel; rapeseed oil; fatty acids ethyl esters; FAEE; bio-additive; thrust; fuel flow; engine efficiency; bench test.

Reference to this paper should be made as follows: Yakovlieva, A., Boichenko, S. and Lejda, K. (2019) 'Evaluation of jet engine operation parameters using conventional and alternative jet fuels', Int. J. Sustainable Aviation, Vol. 5, No. 3, pp.230-248.

Biographical notes: Anna Yakovlieva graduated from the National Aviation University in 2010. She received her PhD in 2016 in Chemical Engineering at National Aviation University and Doctoral degree in Mechanical Engineering at Rzeszow University of Technology in 2018. Since 2019, she is an Associate Professor of the Department of Chemistry and Chemical Technology at the Faculty of Environmental Safety, Engineering and Technologies of the National Aviation University. Her field of scientific interests is renewable jet 
fuels, sustainable transport, alternative energy sources and environmental protection. She is an author and co-author of more than 120 publications, including monographs, textbooks and patents.

Sergii Boichenko graduated from the Kiev Institute of Engineers of Civil Aviation in 1992. In 2004, he received his Doctoral degree in 2005 - Professor title. Since 2005, he is the Scientific Chief of the UkrSREC of Chemmotology and Certification of Fuels, Lubricants and Technical Liquids of the National Aviation University. During 2010-2018, he was the Head of the Ecology Department of the National Aviation University. Since 2018, he is the Dean of the Faculty of Environmental Safety, Engineering and Technologies of the National Aviation University. His field of scientific interests is effective and efficient use of conventional and alternative fuels, and lubricants.

Kazimierz Lejda finished his studies at Krakow University of Technology in 1997. In 1993, he received his Doctor of Sciences degree, in 2011 - Professor title. Since 1973, till nowadays, he has been working at Rzeszow University of Technology starting from constructor, then Senior Assistant, lecturer, Associate Professor and Professor. Today, he occupies position of the Head of the Department of Combustion Engines and Transport of Faculty of Mechanical Engineering and Aeronautics at Rzeszow University of Technology. His field of scientific interests are construction and exploitation of transport, internal combustion engines, transport ecology, transport systems, transport logistics, transport means, diagnostics of transport means.

\section{Introduction}

Modern air transport sector is developing constantly. The world volume of air transportation increases on $4 \%-5 \%$ annually (Kulik et al., 2015). Transport is powered by a single fossil resource, petroleum, that supplies $95 \%$ of the total energy used by world transport. Nowadays civil aviation relies predominantly on a petroleum-derived product kerosene aviation fuel, known as jet fuel (JF). In future, this may raise concerns over fuel supply security and operational cost (Catlos et al., 2018). Along with the situation in exhausting of crude-oil deposits, the state of environment causes a special concern. According to the report by Intergovernmental Panel on Climate Change, transport is responsible for $23 \%$ of world energy-related greenhouse gases emissions with about $2 \%$ from aviation (Sperling and Cannon, 2011). The world transport energy use is projected to increase at the rate of about $2 \%$ per year, and total transport energy use and carbon emissions is projected to be about $80 \%$ higher than current levels by 2030 (IATA, 2011).

The abovementioned factors have caused recent interest in the development of aviation fuels produced from alternative sources. Advancement in chemical technology provides alternative methods of producing $\mathrm{JFs}$, through the conversion of coal, gas or various kinds of biomass (Daggett et al., 2007). Today, scientists work predominantly on developing of renewable JFs (fuels, which are produced from renewable feedstock plant oils, fats, starch or sugar containing plants, organic waste, algae, etc.) and improving its properties (Jansen, 2012; National Academies of Sciences, Engineering, and Medicine, 2016). Along with ensuring availability of feedstock for JFs production and providing high quality of new fuels, durable and reliable operation of aircrafts as well 
decreasing of exhaust gases emissions should be guaranteed (Hileman and Stratton, 2014).

Before using new alternative JFs at commercial flights becomes possible a large and long-term complex of researches should be done (Abu-Taieh and Evon, 2011). Usually, it includes the following stages: lab scale method of alternative fuel production, lab tests of physical-chemical, operation and environmental properties of new JFs', bench tests of new JFs' on model jet engines (JEs), test flights, development of normative documents for new alternative JFs.

This study is devoted to evaluation of JE operation parameters using conventional and alternative JFs during bench tests. The main aim of the study is testing and comparing conventional JF and newly developed alternative JFs in conditions of engine operation and verifying the hypothesis that alternative JFs may be used as working body of JEs providing its reliable and efficient operation.

\section{Literature overview}

Today, alternative JFs are related to renewable energy resources, which have lower price and possess better environmental properties. Numerous states around the world took a responsibility for creating conditions for safe and effective flights according to standards and practices recommended by International Civil Aviation Organization (ICAO). Countries-EU members are planning to reduce by 2030 levels of greenhouse emissions by $40 \%$ comparing to the level of 1990 (IATA, 2011). One of the main instruments for reaching this aim is implementing and using of alternative fuels for aviation. Key requirements to alternative fuels, which are set by ICAO, International Air Transport Association (IATA) and other leading organisations in sphere of civil aviation, are its environmental safety and energy efficiency at all stages of life cycle (starting from producing feedstock up to exhaust gases emissions) (IATA, 2011).

The first feasibility studies for the use of biofuel as a sustainable alternative to petroleum-based JF were conducted in the mid-2000s. Since that time, significant progress in the development and deployment of alternative JFs has been achieved (Blakey et al., 2011). While a wide variety of alternative JFs production pathways have been developed and solutions to most technical can be found, the political and economic boundary conditions still require further development to allow the large-scale production of alternative aviation fuels at affordable prices for airline customers (Hileman and Stratton, 2014).

Alternative JFs should have similar properties to conventional JF of grade Jet A-1 and satisfy requirements of existing JF specification. This provides alternative JFs compatibility with today's Jet A-1 fuel and possibility of using without making some changes in design or construction of today's aircrafts (Boichenko et al., 2013).

Physical-chemical and operation fuel requirements have led to the creation of a quality control specifications, which aim to ensure that different feedstock and refinement techniques are indistinguishable to aircraft operators. These specifications control JFs quality through a series of standard lab tests in order to establish if tested JF meets a range of predetermined values (Boichenko et al., 2013). Lab tests, however, are not a 
direct measure of JE performance parameters (i.e., fuel spray atomisation quality or thermal stability), but instead provide confidence built on extensive operational experience (Hileman and Stratton, 2014; Yildirim and Abanteriba, 2012).

Production of alternative JF refined from non-traditional petroleum source, such biomass, raises concern, if the product meeting the specification, still can provide necessary performance of a JE (Abu-Taieh and Evon, 2011). This is due to the fact that the specification ensures quality control of fuel only and does not provide the complete picture in terms of assessing the suitability of an alternative JF (National Academies of Sciences, Engineering, and Medicine, 2016).

In order to establish the suitability of alternative JF, its complex testing needs to be done (ASTM D4054-09, 2009). It includes both: lab tests, which ensuring new JF properties meeting the specification requirements and bench tests, which ensuring new JF's providing proper JE performance parameters (Chuck and Donnelly, 2014). Bench testing involves establishing how the new fuel actually performs in the airframe and engine fuel systems. It involves assessing, for example, materials and additive compatibility, seal swell and lubricity. Lab and bench tests form the initial step of the fuel approval for commercial use (Yildirim and Abanteriba, 2012).

\section{Experiment methodology}

Within the scope of this study, conventional JF and two alternative JFs were tested on model JE. Alternative JFs were JFs blended with bio-additives in different percentage. Program of bench tests of JFs on JE has foreseen tests of two alternative JFs at certain operation regimes with checking acceleration response time of the engine with further comparing to result, using conventional JF. For this purpose, the quality of fuel was determined according to throttle characteristic of the engine brought to International Standard Atmosphere (ISA): by parameters of thrust, fuel flow (FF), exhaust gas temperature (EGT), compressor delivery pressure, pressure in fuel manifold and acceleration response time depending on engine relative rotor speed.

\subsection{Description of fuel samples}

For fulfilling bench tests conventional JF of grade Jet A-1 was used. This type of fuel was produced by Polski Koncern Naftowy 'ORLEN' (Plok, Poland), and its quality parameters meet requirements of specifications ASTM D1655 (ASTM D1655-17, 2017) and Defence Standard 91-91 (2016).

For obtaining blended JFs, we have used bio-additives, which are fatty acids ethyl esters (FAEE) of rapeseed oil that were produced in the Institute of Bioorganic Chemistry and Petrochemistry of the National Academy of Sciences of Ukraine and were specially modified by vacuum distillation according to the method described in Iakovlieva et al. (2017a). Blended JFs were obtained by mixing conventional JF and bio-additives in quantity $10 \%(\mathrm{v} / \mathrm{v})$ and $20 \%(\mathrm{v} / \mathrm{v})$ (Iakovlieva et al., 2017b). Designation of tested fuel samples is given in Table 1. 
Table 1 Description of fuels samples used for bench tests

\begin{tabular}{llc}
\hline No. & \multicolumn{1}{c}{ Sample description } & Sample designation \\
\hline 1 & Jet fuel of grade Jet A-1 & JF \\
2 & Jet fuel blended with $10 \%$ of modified bio-additive & $\mathrm{JF}+10 \%$ modified FAEE \\
3 & Jet fuel blended with $20 \%$ of modified bio-additive & $\mathrm{JF}+20 \%$ modified FAEE \\
\hline
\end{tabular}

Previous researches were devoted to studying basic physical-chemical properties of JFs blended with rapeseed oil bio-additives and may be found in details in Iakovlieva et al. (2016) and Yakovleva et al. (2017). The generalised data on characteristics of fuel samples used during bench tests are given in Table 2 (Iakovlieva et al., 2017b).

Table 2 Characteristics of quality parameters of fuel samples used during bench tests

\begin{tabular}{|c|c|c|c|c|c|}
\hline No. & Parameter & $\begin{array}{l}\text { ASTM D1655 } \\
\text { jet fuel of } \\
\text { grade Jet A-1 }\end{array}$ & $J F$ & $\begin{array}{c}J F+10 \% \text { of } \\
\text { modified } \\
\text { FAEE }\end{array}$ & $\begin{array}{c}J F+20 \% \text { of } \\
\text { modified } \\
\text { FAEE }\end{array}$ \\
\hline 1 & Density at $t=20^{\circ} \mathrm{C}, \mathrm{kg} / \mathrm{m}^{3}$ & $775-840$ & 794.0 & 804.1 & 811.8 \\
\hline \multirow[t]{6}{*}{2} & Fractional composition & & & & \\
\hline & $t_{i . b .},{ }^{\circ} \mathrm{C}$ & - & 155.22 & 156.1 & 156.0 \\
\hline & $10 \%$ recovery at $t,{ }^{\circ} \mathrm{C}$ & Max. 205 & 169.2 & 168.1 & 169.2 \\
\hline & $50 \%$ recovery at $t,{ }^{\circ} \mathrm{C}$ & report & 186.2 & 188.5 & 193.5 \\
\hline & $90 \%$ recovery at $t,{ }^{\circ} \mathrm{C}$ & report & 217.1 & 249.1 & 340.7 \\
\hline & $98 \%$ recovery at $t,{ }^{\circ} \mathrm{C}$ & Max. 300 & 243.4 & 346.9 & 348.8 \\
\hline \multirow[t]{3}{*}{3} & Kinematic viscosity, $\mathrm{mm}^{2} / \mathrm{s}$, at $t$ & & & & \\
\hline & minus $20^{\circ} \mathrm{C}$ & Max. 8.0 & 3.3 & 4.0 & 4.9 \\
\hline & $20^{\circ} \mathrm{C}$ & - & 1.5 & 1.7 & 2.0 \\
\hline 4 & Flash point, ${ }^{\circ} \mathrm{C}$ & Min. 38 & 43 & 44.5 & 45.5 \\
\hline 5 & Freezing point, ${ }^{\circ} \mathrm{C}$ & Max. -47 & -59 & -57 & -55 \\
\hline 6 & Net heat of combustion, $\mathrm{kJ} / \mathrm{kg}$ & Min. 42,800 & 43,218 & 42,595 & 41,971 \\
\hline
\end{tabular}

\subsection{Description of the JE used for tests fulfilment}

For fulfilling bench tests, the gas-turbine engine of model RU19A-300 was used [Figures 1(a)-1(c)]. Primarily, this type of JE was developed for aircrafts of models Yak-30 and Yak-32. Later, this JE was being installed on aircrafts on models An-24, An-26 and An-30 as auxiliary power unit.

The bench tests were fulfilled on certified engine-test base with specific stand at State Enterprise 410 Factory of Civil Aviation (Kyiv, Ukraine). Main technical characteristics of tested engine are given in Table 3 (ZAO "ANTC Tehnolog", 2001). The main regimes of the engine operation are described in Table 4 (ZAO "ANTC Tehnolog", 2001).

Engine control during the tests was done from the control room with the help of throttle control lever (TCL) connected with fuel pump through transmission. For reaching necessary regime of the engine operation, TCL was stood into position of the required regime. 
Figure 1 External view of engine RU19A-300, (a) frontal view (b) view from the right (c) view from the left

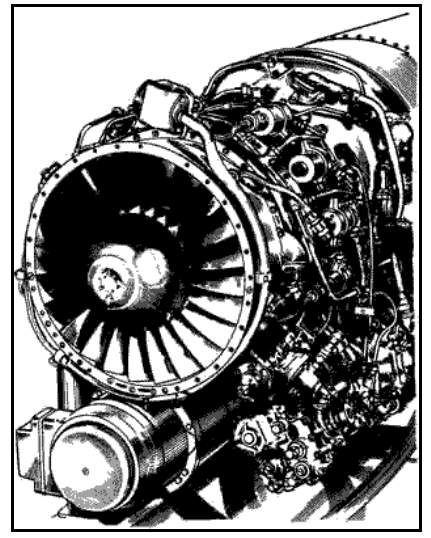

(a)

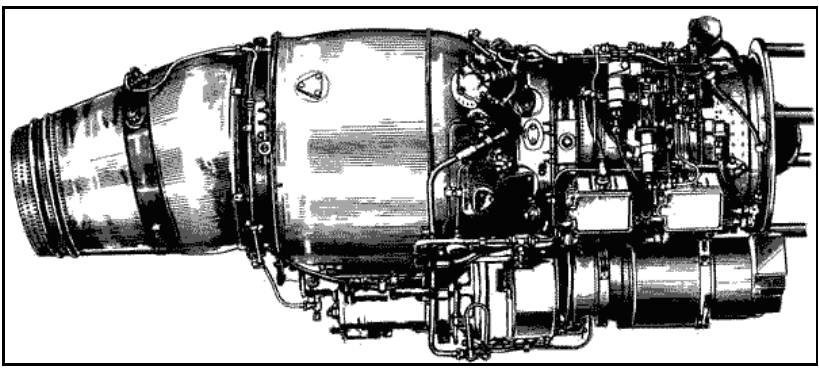

(b)

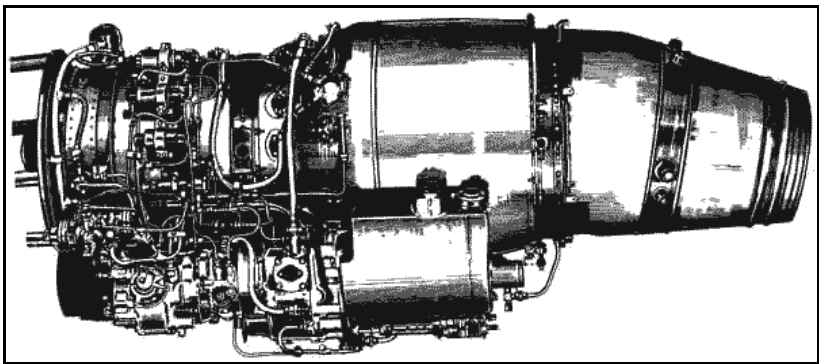

(c)

Source: ZAO “ANTC Tehnolog” (2001) 
Before starting the bench tests, the engine was installed onto stand with supplying to stand systems and normal fuel system. Next, the engine was connected to vessels with JF blended with bio-additives. After that, complex of checking works were done: checking of engine for absence of failures, cracks, rubbish, etc., checking of oil and fuel system for absence of failure or leakages and level of oil in oil tank, checking operation of control systems, including TCL.

Table 3 Main technical characteristics of the engine 'RU19A-300'

\begin{tabular}{|c|c|c|}
\hline 1 & Engine model & RU19A-300 \\
\hline 2 & Type & Gas-turbine \\
\hline 3 & Direction of rotor spinning & $\begin{array}{l}\text { Counterclockwise as viewed from } \\
\text { jet pipe side }\end{array}$ \\
\hline \multirow[t]{10}{*}{4} & Compressor & \\
\hline & - Type & Axial \\
\hline & - Number of stages & 7 \\
\hline & $\begin{array}{l}\text { - Degree of pressure rise at nominal regime on } \\
\text { ground }\end{array}$ & 4.4 \\
\hline & - Maximal air use & $15.8 \mathrm{~kg} / \mathrm{s}$ \\
\hline & Interstage air bleed tape behind the compressor & \\
\hline & - Type & With hydraulic control \\
\hline & - Number & 1 \\
\hline & - Displacement & Behind the fourth stage \\
\hline & $\begin{array}{l}\text { - Closing revolutions (when revolutions increases) } \\
\text { and opening (when revolutions decreases) }\end{array}$ & $63 \pm 2 \%$ \\
\hline \multirow[t]{3}{*}{5} & Combustion chamber & \\
\hline & - Type & Circular with slotted openings \\
\hline & - Number of heads & 9 \\
\hline \multirow[t]{3}{*}{6} & Turbine & \\
\hline & - Type & Axial, gas, jet, binded with fingers \\
\hline & - Number of stages & 1 \\
\hline \multirow[t]{2}{*}{7} & Jet pipe & \\
\hline & - Type & $\begin{array}{l}\text { Subsonic, unregulated, with axis, } \\
\text { inclined down on } 10^{\circ}\end{array}$ \\
\hline \multirow[t]{4}{*}{8} & External dimensions of the engine & \\
\hline & - Length & $1,812 \mathrm{~mm}$ \\
\hline & - Diameter on a housing flange of nozzle assembly & $552 \mathrm{~mm}$ \\
\hline & - Maximal height of the engine with aggregate & $779 \mathrm{~mm}$ \\
\hline 9 & Dry mass of the engine & $222 \mathrm{~kg}$ \\
\hline
\end{tabular}




\subsection{Description of experiment procedure}

The testing was done according to the following testing program (ZAO "ANTC Tehnolog”, 2001):

1 Start the engine with the help of 'start' button. Automatic starting panel gives commands for switching on the starting device, switching on the electric shut-off valve, switching on the ignition system. After some time, fuel comes to igniters, where it is fired by plugs. Then, fuel comes to combustion chamber, where it is burned by plume of starting igniters, the turbine starts working and fuel automatic regulator makes fuel metering. After some time, the ignition system and system of FF starting. After turbine excessive momentum significantly exceeds resistance torque of the JE, the starting device switches off. It happens, when relative rotor speed reaches $31 \pm 2 \%$. Further bring out of the engine to the idling regime is done due to excessive turbine moment. Engine start on JF or JFs blended with bio-additives should be done in accordance to the graph of checking engine operation on ground (Figure 2.) After successful start of the engines, its operation must be tested in the main regimes for accordance to certain parameters (exploitation norms), which are listed in Table 5 (ZAO “ANTC Tehnolog”, 2001).

2 Later, the engine is warmed up at idling regime (relative rotor speed is $n=36 \%$ ), duration of regime is not less than $40 \mathrm{~s}$ with registration of parameters.

3 The engine is brought out to cruise regime 0.8 of nominal $(n=90 \%)$, duration of regime is not less than $40 \mathrm{~s}$ with registration of parameters. When relative rotor speed reaches $63 \pm 2 \%$ tachometric signal equipment gives command for closing interstage air bleed tape.

4 The engine is brought out to nominal regime $(n=97 \%)$, duration of regime is not less than $40 \mathrm{~s}$ with registration of parameters.

5 The acceleration response time is checked: engine is being brought to idling regime during $25 \mathrm{~s}$, parameters are registered and engine is being brought to nominal regime during $1-2 \mathrm{~s}$ and holding at regime during $10 \mathrm{~s}$ with registration of parameters.

6 The engine is brought out to 0.75 of nominal regime $(n=80 \%)$, duration of regime is not less than $40 \mathrm{~s}$ with registration of parameters.

7 The engine is brought out smoothly to idling regime during $25 \mathrm{~s}$ with further stop, measuring of engine rotor run-out and registration of parameters. When rotor speed reaches $63 \pm 2 \%$ tachometric signal equipment gives command for opening interstage air bleed tape. The engine is stopped by moving TCL from $80+5 \%$ relative rotor speed to 'stop' position. During stopping, the rotor run-out should be checked from idling revolutions to rotor stop. The run-out time should be not less than $35 \mathrm{~s}$.

8 Items 1-7 were repeated for engine operation for two kinds of JFs blended with bio-additives.

9 Perform the protocol of bench tests. 
Table 4 Main operations regimes of the engine 'RU19A-300'

\begin{tabular}{lcccccc}
\hline $\begin{array}{l}\text { Operation } \\
\text { regime }\end{array}$ & \multicolumn{2}{c}{ Engine rotor speed } & $\begin{array}{c}\text { Thrust on } \\
\text { stand, } N\end{array}$ & $\begin{array}{c}\text { SFF, } \mathrm{kg} \text { of } \\
\text { fuel } / \mathrm{N} h\end{array}$ & $\begin{array}{c}\text { Time of constant } \\
\text { operation, min }\end{array}$ & $\begin{array}{c}\text { Operation time } \\
\text { during resource, } \\
\text { hours }\end{array}$ \\
\cline { 2 - 6 } Nominal & $16000_{-165}^{+83}$ & $97_{-1.0}^{+0.5}$ & $\begin{array}{c}\text { Not less } \\
\text { than } 7,845\end{array}$ & $\begin{array}{c}\text { Not more } \\
\text { than } 10.98\end{array}$ & Not limited & Not limited \\
$\begin{array}{l}\text { Cruise } 0.9 \\
\text { of nominal }\end{array}$ & $15100_{-83}$ & $94_{-0.5}$ & $\begin{array}{c}\text { Not less } \\
\text { than } 7,061\end{array}$ & $\begin{array}{c}\text { Not more } \\
\text { than } 10.86\end{array}$ & Not limited & Not limited \\
0.8 nominal & $14850_{-83}^{+83}$ & $90_{-0.5}^{+0.5}$ & - & - & Not limited & Not limited \\
Idling & $5942_{-415}^{+495}$ & $36_{-2.5}^{3.0}$ & $\begin{array}{c}\text { Not more } \\
\text { than } 490\end{array}$ & - & $\begin{array}{c}\text { Not more than } \\
\text { on ground, not } \\
\text { limited at flight }\end{array}$ & Not limited \\
\hline
\end{tabular}

Figure 2 Graph-cyclogram for checking engine operation on ground

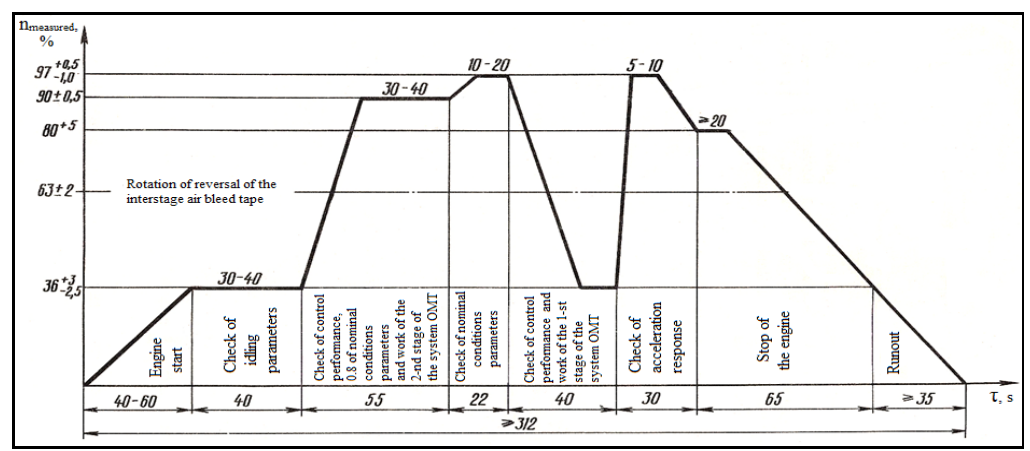

Source: ZAO “ANTC Tehnolog” (2001)

Table 5 Exploitation norms of regime parameters

\begin{tabular}{lcccc}
\hline $\begin{array}{l}\text { Operation } \\
\text { regimes }\end{array}$ & $\begin{array}{c}\text { Relative rotor } \\
\text { speed, } \%\end{array}$ & EGT, ${ }^{\circ} \mathrm{C}$ & $\begin{array}{c}\text { Oil pressure at } \\
\text { engine inlet, } \mathrm{MPa} a\end{array}$ & $\begin{array}{c}\text { Time of engine constant } \\
\text { operation, min }\end{array}$ \\
\hline $\begin{array}{l}\text { Nominal } \\
\begin{array}{l}\text { Cruise } 0.9 \\
\text { of nominal }\end{array}\end{array}$ & $97_{-1.0}^{+0.5}$ & Not more than 720 & $0.34-0.39$ & Not more than 5 min \\
0.8 nominal & $90 \pm 0.5$ & Not more than 700 & $0.34-0.39$ & Not limited \\
Idling & $36_{-2.5}^{+3.0}$ & Not more than 700 & $0.34-0.39$ & $\begin{array}{c}\text { Not limited } \\
\text { Rotation }\end{array}$ \\
$\begin{array}{l}\text { Not less than } 730 \\
11\end{array}$ & - & Not less than 0.1 & $\begin{array}{c}\text { Not more than } 30 \text { on } \\
\text { ground, not limited at } \\
\text { flight }\end{array}$ \\
\hline
\end{tabular}

During the bench tests, the following engine operation parameters were measured:

- $\quad$ relative rotor speed $n, \%$

- $\quad$ engine inlet temperature $t_{e . i n .},{ }^{\circ} \mathrm{C}$ 
- $\quad$ barometric pressure, $B_{\text {atm }}, \mathrm{mm} \mathrm{Hg}$

- $\quad$ thrust, $R, \mathrm{~N}$

- $\quad$ pressure in fuel manifold, $P_{f . m}$., $\mathrm{MPa}$

- $\quad$ jet pipe temperature, $t_{j . p .},{ }^{\circ} \mathrm{C}$

- $\mathrm{FF}, G, 1 /$ hour

- acceleration response time, $\mathrm{s}$.

Values of rotor speed, thrust, EGT and fuel consumption, which were measured during bench tests need to be recalculated to the ISA using formulae presented below. ISA is considered to be: barometric pressure $B_{0}=760 \mathrm{~mm} \mathrm{Hg}$ and external temperature $t_{0}=15^{\circ} \mathrm{C}$ (Tereshchenko et al., 2015; Asgari et al., 2013).

Relative rotor speed (Tereshchenko et al., 2015):

$$
n_{I S A}=n_{\exp } \cdot \sqrt{\frac{288}{t_{0}+273}}, \mathrm{rpm}
$$

where $n_{I S A}$ - relative rotor speed at ISA, $\%, n_{\exp }$ - experimental value of rotor speed, $\%$ and $t_{0}$ - temperature at ISA, ${ }^{\circ} \mathrm{C}$.

Engine thrust (Tereshchenko et al., 2015):

$$
R_{I S A}=R_{\exp } \cdot \frac{760}{B_{0}-\frac{\Delta P_{a}^{*}}{13.6}}, \mathrm{~N}
$$

where $R_{I S A}$ - thrust at ISA, N, $R_{\exp }$ - experimental value of thrust, $\mathrm{N}, B_{0}$ - barometric pressure, $\mathrm{mm} \mathrm{Hg}$ and $\Delta P_{a}^{*}$ - stagnation pressure reduction, $\mathrm{mm}$ w.g., $\mathrm{kg} / \mathrm{m}^{2}$.

Fuel flow (Tereshchenko et al., 2015):

$$
G_{I S A}=G_{\text {exp }} \cdot \frac{760}{B_{0}-\frac{\Delta P_{a}^{*}}{13.6}} \cdot \sqrt{\frac{288}{t_{0}+273}}, 1 / \mathrm{h}
$$

where $G_{I S A}-\mathrm{FF}$ at ISA, 1/h, $G_{\exp }$ - experimental value of FF, $1 / \mathrm{h}, B_{0}$ - barometric pressure, $\mathrm{mm} \mathrm{Hg}, \Delta P_{a}^{*}$ - stagnation pressure reduction, $\mathrm{mm}$ w.g., $\mathrm{kg} / \mathrm{m}^{2}$ and $t_{0}-$ temperature at ISA, ${ }^{\circ} \mathrm{C}$.

Exhaust gas temperature (Tereshchenko et al., 2015):

$$
t_{E G T . I S A}=t_{E G T \text { exp. }}+273 \cdot \frac{288}{t_{0}+273}-273
$$

where $t_{E G T \cdot I S A}-\mathrm{EGT}$ at ISA, ${ }^{\circ} \mathrm{C} ; t_{E G T \text { exp }}-$ experimental value of EGT, ${ }^{\circ} \mathrm{C}$ and $t_{0}-$ temperature at ISA, ${ }^{\circ} \mathrm{C}$.

Experimental volume FF may be translated into standard mass FF by its multiplication by fuel density (Tereshchenko et al., 2015):

$$
G=G_{\exp } \cdot \rho, \mathrm{kg} / \mathrm{h}
$$

where $G$ - standard mass $\mathrm{FF}, \mathrm{kg} / \mathrm{h}, G_{\exp }$ - experimental volumetric value of $\mathrm{FF}, \mathrm{l} / \mathrm{h}$ and $\rho-\mathrm{JF}$ density, $\mathrm{kg} / \mathrm{m}^{3}$. 
Table 6 Experimental results of JFs bench tests on engine 'RU19A-300'

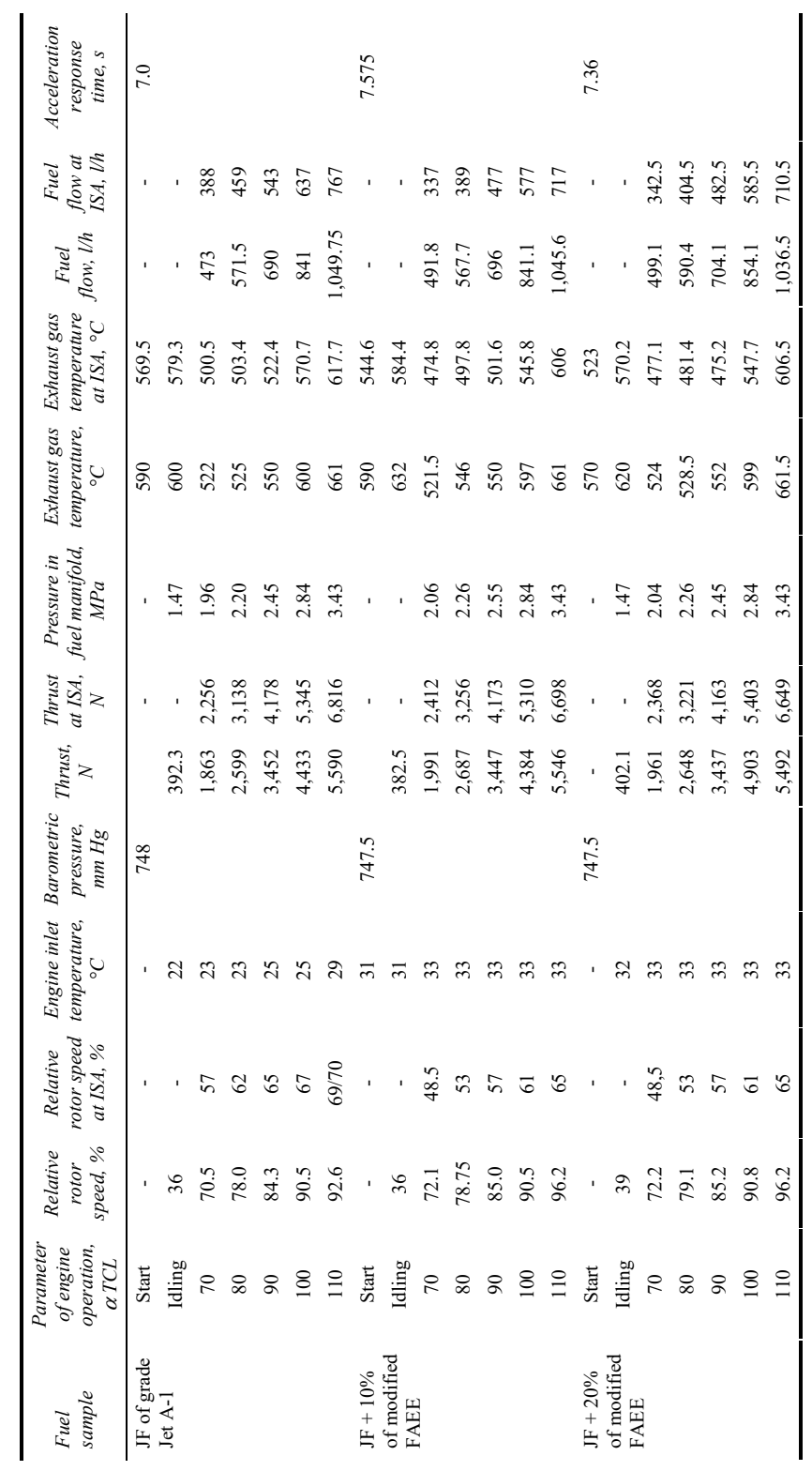




\section{Experiment results and discussion}

Experimental results on listed above parameters were brought into protocols. Generalised results for conventional JF and two kinds of blended JFs are presented in Table 6 . Table 6 includes both experimental data and data on rotor speed, engine thrust, FF and EGT, brought to ISA conditions, which were calculated using formulae (1)-(4).

\subsection{Thrust}

Figure 3 shows the result on JE's thrust determination using conventional JF, JF blended with $10 \%$ of modified FAEE bio-additive and JF blended with $20 \%$ of modified FAEE bio-additive. Thrust evolution is presented as a function of engine operation conditions angle $\alpha$ of the TCL. From Figure 3, it is clearly seen that all the tested fuels produced almost the same JE's thrust. At JE acceleration to 0.8 of nominal regime $(\alpha \approx 80) \mathrm{JFs}$ blended with $10 \%$ and $20 \%$ of modified FAEE show higher thrust values. During acceleration to nominal regime better thrust is produced by conventional JF. However, the variations in JE's thrust are insignificant and are within the acceptable limits.

At the same time, Figure 3 does not characterise the absolute value of thrust produced by the JE. It describes only response of JE operation to the position of the TCL. It is known that thrust of the JE is stipulated by the degree of air compression produced by the compressor. The work of the compressor is provided by the rotor spinning. Thus, the JE's thrust is directly proportional to the work performed by the rotor that is characterised by rotor speed. Taking into account the above mentioned, the JE's thrust was considered as a function of rotor speed (Figure 4).

Figure 3 JE's thrust as a function of engine operating conditions when powered with JF Jet A-1, $\mathrm{JF}+10 \%$ of modified FAEE, $\mathrm{JF}+20 \%$ of modified FAEE (see online version for colours)

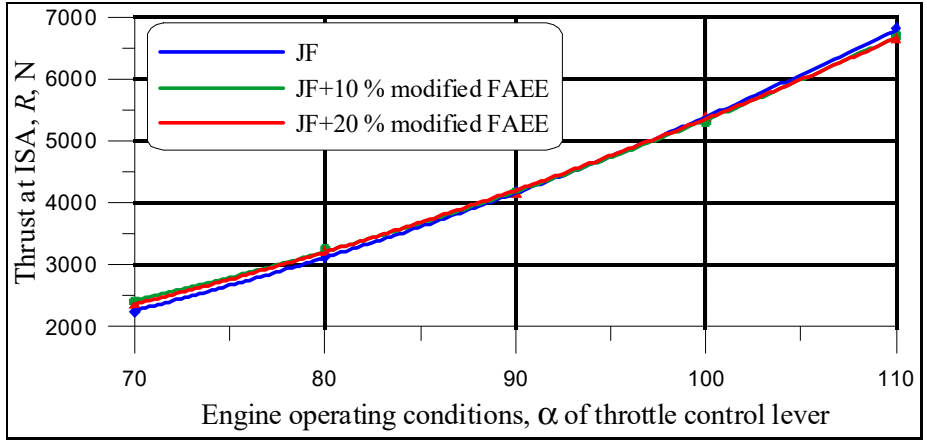

The results on Figure 4 show the significant difference in thrust produced by conventional JF and blended JFs. Acceleration of JE from idling regime to 0.8 of nominal and producing thrust about 4,000 $\mathrm{N}$ when powered by blended JFs is provided by less relative rotor speed $(48.5 \%)$ comparing to conventional JF, when the same thrust is provided by higher relative rotor speed (about 58\%). It is seen that the same values of 
JE's thrust are reached at lower rotor speed when JE uses blended JFs, comparing to conventional JF. Less work is done by the JE for producing the same thrust. The results show that blended JFs are more efficient comparing to conventional JF of grade Jet A-1. At the same time, it was found no significant difference in JE's thrust produced by both JFs blended with modified FAEE bio-additives.

Figure 4 JE's thrust as a function of engine rotor speed when powered with JF JET A-1, JF $+10 \%$ of modified FAEE, JF $+20 \%$ of modified FAEE (see online version for colours)

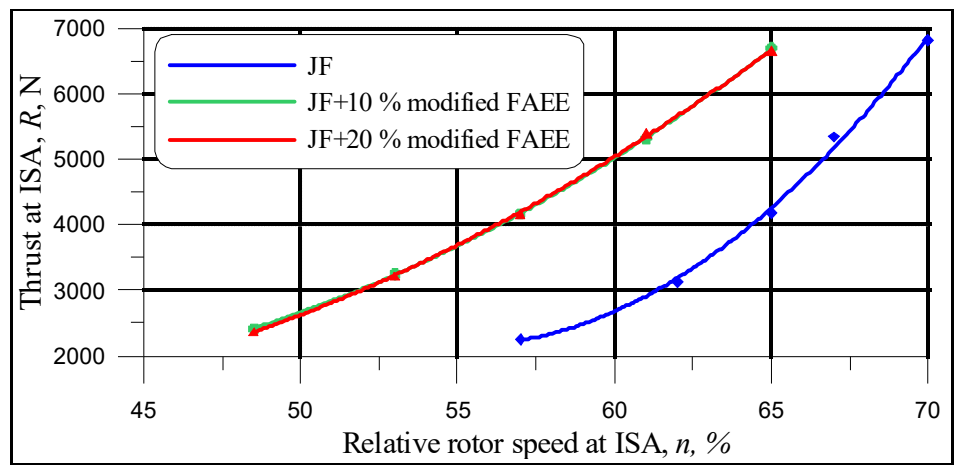

\subsection{Fuel flow}

Figure 5 shows the result on FF determination using conventional JF, JF blended with $10 \%$ of modified FAEE bio-additive and JF blended with $20 \%$ of modified FAEE bio-additive. The parameters of FF are presented as a function of engine operation conditions - angle $\alpha$ of a TCL. Figure 5 presents data on volumetric FF of the JE.

From Figure 5, it may be seen that JFs blended with $10 \%$ and $20 \%$ of modified FAEE have presented a significant reduction in FF comparing to conventional JF. The FF for JF blended with $10 \%$ of modified FAEE bio-additive is on $50-70 \mathrm{l} / \mathrm{h}$ less that comparing to conventional JF. At the same time, JF with higher content of bio-additive $(20 \%)$ has provided slightly greater $\mathrm{FF}$, that is on $5-15 \mathrm{l} / \mathrm{h}$ more than for JF with $10 \%$ of bio-additive. Evidently, this positive result on FF reduction was achieved due to the higher densities of blended JFs.

The JE's FF was also considered as a function of rotor speed (Figure 6). The results on Figure 6 show the difference in FF provided by conventional JF and blended JFs. It is seen from Figure 6 that the same values FF are provided at lower rotor speed when JE uses blended JFs, comparing to conventional JF. We can see that FF at 0.9 of nominal operation regime (provided by relative rotor speed $=61 \%$ ) is equal to $577 \mathrm{l} / \mathrm{h}$ for blended JF with $10 \%$ of bio-additive and $585 \mathrm{l} / \mathrm{h}$ for blended JF with $20 \%$ of bio-additive, while the same regime for conventional JF (provided by relative rotor speed $=67 \%$ ) is reached at $\mathrm{FF}=637 \mathrm{l} / \mathrm{h}$. 
When correlating the obtained results on FF with results on JE's thrust, we can make a general conclusion that less work should be done by the JE to reach the same performance characteristics (thrust and FF) when it is powered by JFs blended with bio-additives. Thus, this result allows us concluding on greater energy and fuel efficiency of new blended JFs.

Figure $5 \mathrm{FF}$ as a function of engine rotor speed when powered with JF Jet A-1, JF $+10 \%$ of modified FAEE, JF $+20 \%$ of modified FAEE (see online version for colours)

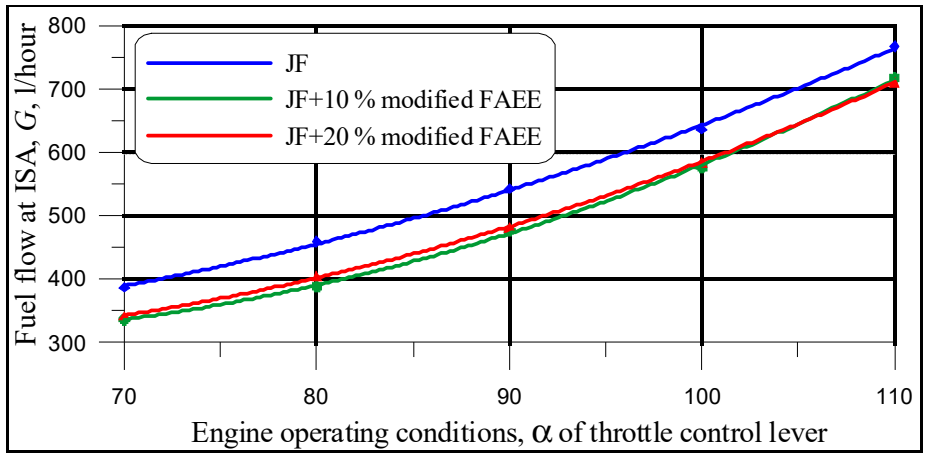

Figure $6 \mathrm{FF}$ as a function of engine rotor speed when powered with JF Jet A-1, JF $+10 \%$ of modified FAEE, JF $+20 \%$ of modified FAEE (see online version for colours)

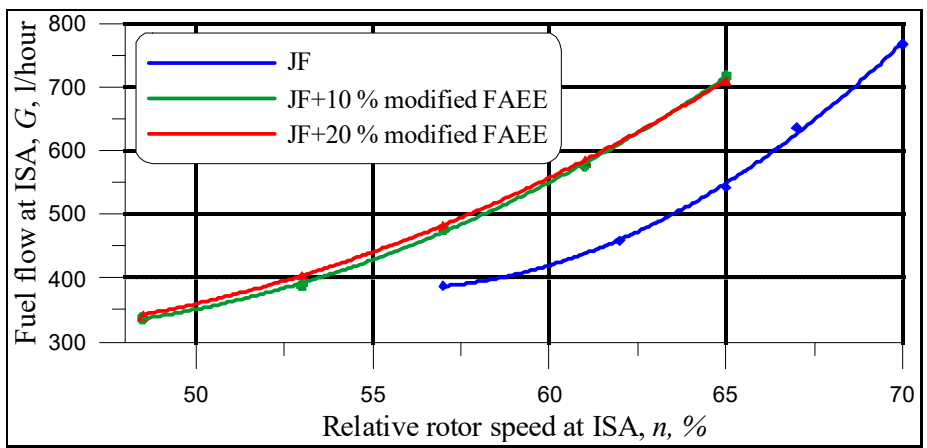

\subsection{Pressure in fuel manifold}

Figure 7 shows the result on determination pressure in fuel manifold before injection into combustion chamber using conventional JF, JF blended with $10 \%$ of modified FAEE bioadditive and JF blended with $20 \%$ of modified FAEE bio-additive. The studied parameter is presented as a function of engine operation conditions - angle $\alpha$ of a TCL. 
From Figure 7, it is clearly seen that pressure in fuel manifold that is generated during supply all the tested fuels does not show significant differences. During JE acceleration from idling regime to 0.8 of nominal regime $(\alpha \approx 80)$ JFs blended with $10 \%$ and $20 \%$ of modified FAEE cause higher pressure in fuel manifold. Probably, this may be explained by greater viscosity values of blended JFs. At the same time during acceleration to 0.9 of nominal regime $(\alpha \approx 90 \rightarrow 100)$, the difference in pressure becomes less. And at nominal regime ( $\alpha \approx 110$ ), all the tested fuels cause the same values of pressure in fuel manifold. In general, all the experimental values of pressure in fuel manifold are within the acceptable limits.

Figure 7 Pressure in fuel manifold as a function of engine operating conditions when powered with JF Jet A-1, JF $+10 \%$ of modified FAEE, JF $+20 \%$ of modified FAEE (see online version for colours)

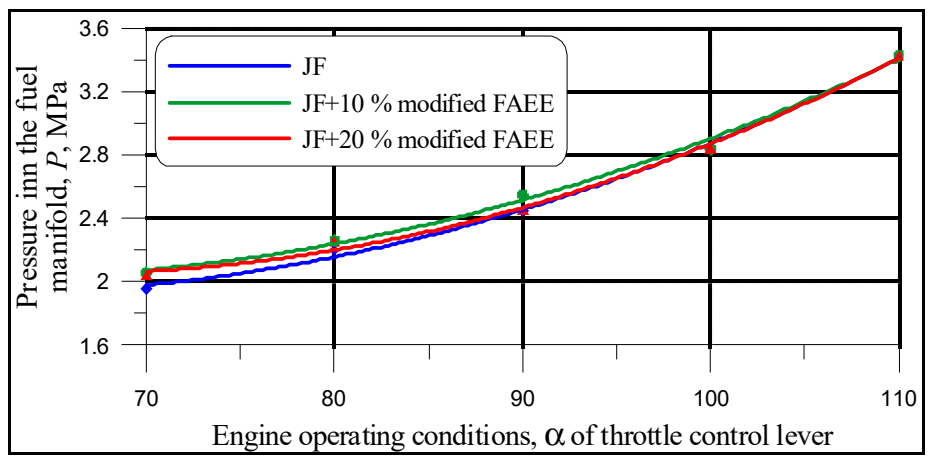

\subsection{Exhaust gas temperature}

Figure 8 shows the result on measuring EGT in the jet pipe of the JE using conventional JF, JF blended with $10 \%$ of modified FAEE bio-additive and JF blended with $20 \%$ of modified FAEE bio-additive. The studied parameter is presented as a function of engine operation conditions - angle $\alpha$ of a TCL.

From Figure 8, it is clearly seen that using conventional JF generate higher gas temperature in the jet pipe comparing to JFs blended with bio-additives. Here, we can observe a gradual decrease of EGT with increasing content of bio-additive in JF blends. This effect is considered to be positive because of the several reasons.

First, temperature decrease may positively influence on materials and structure of JE exhausts system. It is well known that metal alloys (Kulik et al., 2015) used for jet pipe construction, have to be resistant to extremely high temperatures, produced by hot gas stream. Thus, using blended JFs may contribute to durability of JE's construction.

Second, high temperature, produced by gas stream is the reason for atmospheric nitrogen oxidation and formation of nitrogen oxides $\left(\mathrm{NO}_{\mathrm{x}}\right)$ emissions. There is a direct dependence between gas temperature and amounts of $\mathrm{NO}_{\mathrm{x}}$ emissions (Franchuk and Isaienko, 2004). From this statement, we can conclude that decreasing of EGT may positively contribute to overall reduction of $\mathrm{NO}_{\mathrm{x}}$ emissions (Kulik et al., 2015). 
Figure 8 EGT as a function of engine rotor speed when powered with JF Jet A-1, JF $+10 \%$ of modified FAEE, JF $+20 \%$ of modified FAEE (see online version for colours)

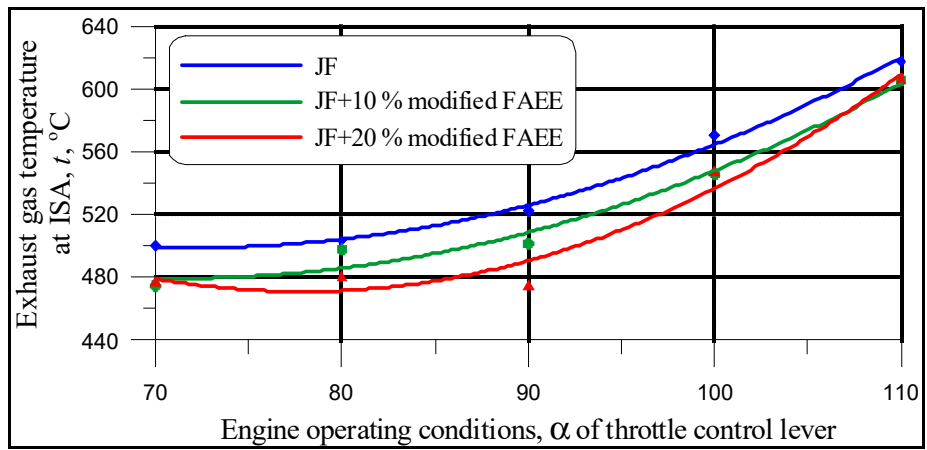

\subsection{Relative rotor speed}

Figure 9 shows the result on studying relative rotor speed of the JE using conventional JF, JF blended with $10 \%$ of modified FAEE bio-additive and JF blended with $20 \%$ of modified FAEE bio-additive. The studied parameter is presented as a function of engine operation conditions - angle $\alpha$ of a TCL.

Figure 9 Rotor speed as a function of engine rotor speed when powered with JF Jet A-1, JF $+10 \%$ of modified FAEE, JF $+20 \%$ of modified FAEE (see online version for colours)

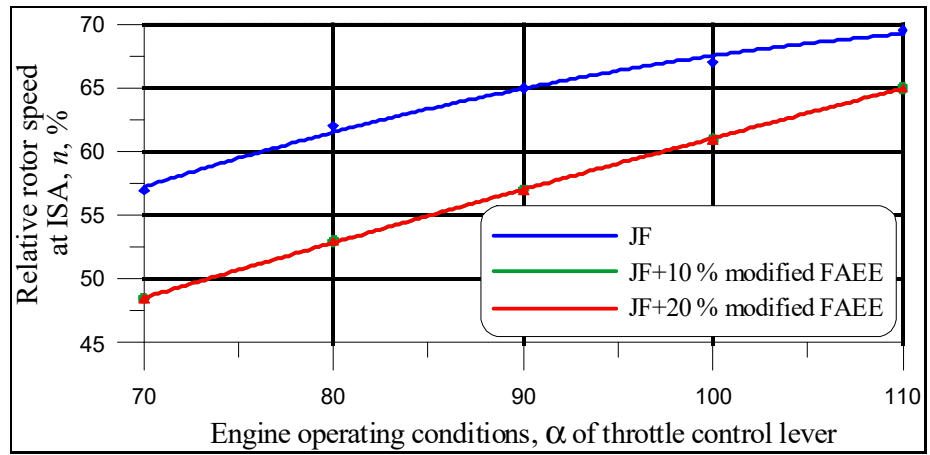

From Figure 9, it may be seen that JFs blended with $10 \%$ and $20 \%$ of modified FAEE have presented a significant reduction in relative rotor speed generated by the JE comparing to conventional JF. When correlating the obtained results on relative rotor speed with results on JE's thrust and FF, we can make a general conclusion that using blended JFs is more efficient comparing to conventional JF as less work should be done by the JE to reach the same performance characteristics (thrust and FF). Thus, these results allow us concluding on greater energy and fuel efficiency of new blended JFs. 


\subsection{Acceleration response time}

The final parameter that was controlled during bench tests of JF samples is acceleration response time. This parameter characterises the time necessary for the JE to reach its maximal power (maximal thrust) (Rolls-Royce plc, 1996). Acceleration response time was measured as a time for acceleration from idling regime to nominal regime. The results of measurements are shown at Figure 10.

Figure 10 Acceleration response time for je when powered with JF Jet A-1, JF $+10 \%$ of modified FAEE, JF $+20 \%$ of modified FAEE (see online version for colours)

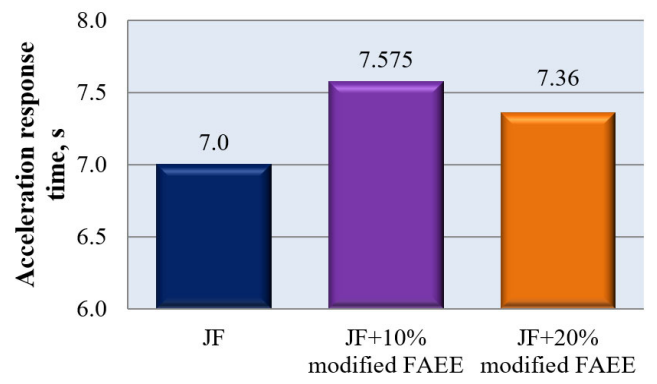

From Figure 10, it may be seen that using JFs blended with bio-additives results in slightly higher acceleration response time of JE comparing to conventional JF. However, the time difference is not significant and completely within exploitation norms for the tested JE.

\section{Conclusions}

The results of bench tests of operation parameters of JE using conventional JF and two receipts of blended JFs, which contained $10 \%$ and $20 \%$ of modified FAEE bio-additive, allowed making the following conclusions:

- Using JFs blended with bio-additives leads to improvement of JE thrust characteristics, as the same values of JE's thrust may be reached at lower rotor speed when JE powered with blended JFs, comparing to conventional JF; blended JFs are more efficient comparing to conventional JF of grade Jet A-1; at the same time, it was found no significant difference in JE's thrust produced by both blended JFs samples.

- Using JFs blended with bio-additives leads to significant reduction of FF comparing to conventional JF; evidently, this positive result on FF reduction was achieved due to the higher densities of blended JFs.

- Using JFs blended with bio-additives leads to reduction of EGT in the jet pipe comparing to conventional JFs; temperature decrease will have positive effect on materials and structure of JE exhaust system improving its durability to high gas 
temperature; decreasing of EGT will also contribute to overall reduction of $\mathrm{NO}_{\mathrm{x}}$ emissions.

- Using JFs blended with bio-additives leads to reduction of relative rotor speed of JE comparing to conventional JF; it was found that less work is done by the JE for producing the same thrust, thus blended JFs stipulate more efficient JE operation.

- Using JFs blended with bio-additives results in slightly bigger acceleration response time of JE comparing to conventional JF; however, the time difference is not significant and completely within exploitation norms for the tested JE.

In the result of bench tests, it was concluded that operational parameters of the JE powered with new blended JFs completely satisfy exploitation norms, which are set in specification for tested JE. Thus, the proposed JFs blended JFs, which contain $10 \%$ and $20 \%$ of modified FAEE bio-additive may be used as a working body of the JE and do not require its design changes.

\section{References}

Abu-Taieh, C. and Evon, J. (2011) Technology Engineering and Management in Aviation: Advancements and Discoveries, Information Science Reference, IGI Global, Hershey, USA.

Asgari, H., Chen, X. and Sainudiin, R. (2013) 'Modelling and simulation of gas turbines', International Journal of Modelling, Identification and Control, Vol. 25, No. 3, pp.1-15.

ASTM D1655-17 (2017) Standard Specification for Aviation Turbine Fuels.

ASTM D4054-09 (2009) Standard Practice for Qualification and Approval of New Aviation Turbine Fuels and Fuel Additives.

Blakey, S., Rye, L. and Wilson, C.W. (2011) 'Aviation gas turbine alternative fuels: a review', Proceedings of the Combustion Institute, Vol. 33, pp.2863-2885.

Boichenko, S., Iakovlieva, A. and Vovk, O. (2013) 'Traditional and alternative jet fuels: problems of quality standardization', Journal of Petroleum \& Environmental Biotechnology, Vol. 4, No. 3, pp.28-35.

Catlos, M., Kurdel P., Sedlakova, A.N., Labun, J. and Ceskovic, M. (2018) 'Continual monitoring of precision of aerial transport objects', 2018 XIII. International Scientific Conference - New Trends in Aviation Development (NTAD), pp.30-35.

Chuck, C.J. and Donnelly, J. (2014) 'The compatibility of potential bioderived fuels with jet A-1 aviation kerosene', Applied Energy, Vol. 118, pp.83-91.

Daggett, D.L., Hendricks, R.C., Walther, R. and Corporan, E. (2007) Alternative Fuels for Use in Commercial Aircrafts, The Boeing Company.

Defence Standard 91-91 (2016) Turbine Fuel, Kerosine Type, Jet A-1. NATO Code: F-35 Joint Service Designation: AVTUR, No. 9.

Franchuk, G.M. and Isaienko, V.M. (2004) Ecologiia, aviatsiia, cosmos, in Ukrainian, NAU, Kyiv.

Hileman, J.I. and Stratton, R.W. (2014) 'Alternative jet fuel feasibility', Transport Policy, Vol. 34, pp.52-62.

Iakovlieva, A., Boichenko, S., Lejda, K., Vovk, O. and Shkilniuk, I. (2017a) 'Vacuum distillation of rapeseed oil esters for production of jet fuel bio-additives', Proceedia Engineering, Vol. 187, pp.363-370, DOI: doi.org/10.1016/j.proeng.2017.04.387.

Iakovlieva, A., Vovk, O., Boichenko, S., Lejda, K. and Kuszewski, H. (2017b) 'Physical-chemical properties of jet fuels blends with components derived from rapeseed oil', Journal of Chemistry \& Chemical Technology, Vol. 10, No. 1, pp.485-492. 
Iakovlieva, A., Vovk, O. and Boichenko, S. (2016) 'Experimental study of rape oil esters influence on physical-chemical properties of jet fuels', Proceedings of the 19th Conference for Junior Researchers 'Science - Future of Lithuania' Transport Engineering and Management, Vilnius, 6 May, pp.85-89.

IATA (2011) Vision 2050. Report, International Air Transport Organization, Montreal, Geneva [online] https://www.iata.org/pressroom/facts_figures/Documents/vision-2050.pdf (accessed 10 November 2012).

Jansen, R.A. (2012) Second Generation Biofuels and Biomass: Essential Guide for Investors, Scientists and Decision Makers, Wiley-VCH Verlag GmbH, Weinheim, Germany.

Kulik, N.S., Aksenov, A.F., Yanovskii, L.S. et al. (2015) Aviatsionnaya himmotologiia: topliva dlia aviatsionnyh dvigatelei. Teoreticheskiie I inzhenerniie osnovy primeneniia, in Russian, NAU, Kyiv.

National Academies of Sciences, Engineering, and Medicine (2016) Commercial Aircraft Propulsion and Energy Systems Research: Reducing Global Carbon Emissions, The National Academies Press, Washington, DC, DOI: 10.17226/23490.

Rolls-Royce plc (1996) The Jet Engine, Technical Publications Department, Rolls-Royce plc, Derby, England

Sperling, D. and Cannon, J.S. (2011) Reducing Climate Impacts in the Transportation Sector, Springer Science \& Business Media, Springer, Dordrecht.

Tereshchenko, Y.M. et al. (2015) Teoriia teplovyh dvyhuniv. Gazodynamichnii rozrahunok elementiv gazoturbinnyh dvyhuniv, in Ukrainian, NAU, Kyiv.

Yakovleva, A., Boichenko, S., Leida, K., Vovk, O. and Kuzhevskii, K. (2017) 'Influence of rapeseed oil ester additives on fuel quality index for air jet engines', Chemistry and Technology of Fuels and Oils, Vol. 53, No. 3, pp.308-317, DOI: doi.org/10.1007/s10553-0170807-5.

Yildirim, U. and Abanteriba, S. (2012) 'Manufacture, qualification and approval of new aviation turbine fuels and additives', Proceedia Engineering, Vol. 49, pp.310-315.

ZAO "ANTC Tehnolog" (2001) Aviatsionnyi turboreaktivnyi dvigatel RU 19A-300. Rukovodstvo po ekspuatatsii I tehnicheskomu obsluzhivaniiu, in Russian.

\section{List of abbreviations}

\begin{tabular}{ll}
\hline EGT & Exhaust gas temperature \\
FAEE & Fatty acids ethyl esters \\
FF & Fuel flow \\
ICAO & International Civil Aviation Organization \\
ISA & International Standard Atmosphere \\
JE & Jet engine \\
JF & Jet fuel \\
NOx & Nitrogen oxides \\
SFF & Specific fuel flow \\
TCL & Throttle control lever \\
\hline
\end{tabular}

